\title{
The Consumer-Private Labels Bond and the Store Loyalty: The Role of Satisfaction
}

\author{
Maryem Trabelsi \\ Department of Business Administration, College of Business, Al Jouf University, Al Jouf, KSA \\ Email: meriem.trabelsi55@yahoo.com
}

How to cite this paper: Trabelsi, M. (2020) The Consumer-Private Labels Bond and the Store Loyalty: The Role of Satisfaction. Open Journal of Business and Management, 8, 428-451.

https://doi.org/10.4236/ojbm.2020.82027

Received: December 20, 2019

Accepted: January 18, 2020

Published: January 21, 2020

Copyright $\odot 2020$ by author(s) and Scientific Research Publishing Inc. This work is licensed under the Creative Commons Attribution International License (CC BY 4.0).

http://creativecommons.org/licenses/by/4.0/

(c) (i) Open Access

\begin{abstract}
This research aims to understand the relationship between customers' satisfaction with private labels and their loyalty toward the stores that own and sell these private labels. 256 Tunisian customers participated in this research by fulfilling a questionnaire prepared to collect the data about their opinions and attitudes toward private labels and stores that sell these labels. Researchers add customers' trust and customers' attachment with the private labels as a variable mediating the relationships between customers' satisfaction with the brands and customers' loyalty to the stores. Results show that customers' satisfaction with private labels directs customers' loyalty toward stores that sell these labels. While this relation is not affected by the existence of trust and attachment to the private labels. Also, results found that trust with private label doesn't yield to brand attachment. According to research results, researchers recommend marketers to focus their efforts on marketing private labels and satisfying customers' needs in order to gain their loyalty toward the stores which will result in more benefits for the store in general.
\end{abstract}

\section{Keywords}

Private Labels, Trust, Attachment, Loyalty and Satisfaction

\section{Introduction}

Customer satisfaction has been the main stone for the whole marketing philosophy. All marketing activities are derived from customers and directed toward them. Marketers' main interest is to know how to fulfill customers' needs and to take the customers into the level of satisfaction. This satisfaction is at the top of the mountain of marketing activities. Every store reaches the top tries to keep up the good work in order to stay at that position. A store that offers products that fulfill customers' needs has reached the top, but the challenge that stores strive to 
make it is to keep their customers in a continued and long term relationship with them, i.e. customers' loyalty. One of the tools stores use to gain purchases' patronage is to make their own labels. They might not produce it by themselves; rather they make agreements with some producers or distributors to pack some products and label them with private labels owned by the stores.

This research aims to figure out the relationship between customers' satisfaction with private labels and store loyalty with the existence of brand trust and brand attachment. A relationship between product trust and product attachment will be tested, finally the direct relationship between customers' satisfaction with private labels and store loyalty will be tested. These direct and indirect relationships will be tested to show the difference and to check the effect of the mediation variables.

The first part of the paper presents the theoretical framework which is an extended elaboration for the main terminologies of this research (Consumer satisfaction, Brand Attachment, Brand Trust and Brand Loyalty). The second part presents the empirical part of the research which includes research problem and objectives, research model and hypotheses development, research methodology, data analysis and discussion, and finally in the last part there will show the conclusion and the recommendations of the research.

\section{Theoretical Framework}

\subsection{Consumer Satisfaction}

Marketing literature is replete with research studies that have examined the concept of satisfaction, a concept that has always been considered as a vital condition for the development of a consumer-brand relationship, for brand loyalty and companies' prosperity and survival in high competitive markets. However, while reviewing these abundant academic studies, one can easily notice the absence of any consensus regarding its definition, its nature and its measurement. In fact, since its first academic use in 1967 by Cardozo, researchers have failed in developing and approving a unique, universal and unequivocal definition that clearly differentiate satisfaction from close concepts. According to Giese and Cote (2000) [1], the absence of a consensual definition of consumer satisfaction grounded on the "consumers' views of the relevant satisfaction situation" (p3) prevents the creation of "a unified, comparable body of research" and limits hence "the degree to which generalizations can be developed (...) the degree to which results can be explained, justified and compared" (p2). Moreover, this lack gives raise to a plain misunderstanding of the concept's theoretical singularities and conceptual boundaries. For instance, satisfaction was enormously confused with service quality in theory and practice (Oliver, 1999) [2] since both of them were commonly perceived as the "assessment of the variation between the consumer's perception and expectations of service levels" (Bei and Chiao, 2001, p126) [3] especially in the study of Zeithaml et al. (1985) [4] where service quality was defined as "the evaluation of the perceived discrepancy between prior 
expectations and the actual performance of the product", a controversial definition that shed light on the weaknesses of the prior satisfaction conceptualizations and brought those authors to reanalyze their definition and precise three years later that service quality refers to an overall judgment assuming the superiority of the offered service while satisfaction is generally associated with a particular experience or transaction (Najjar and Zaiem, 2011) [5]. In sum, after reviewing more than 20 definitions used during the last three decades, Giese and Cote (2000) [1] highlighted that despite the inexistence of a unified definition of satisfaction, the diverse conceptualizations have three common components. In fact, consumer satisfaction has always been considered as an emotional and/or cognitive and/or conative response related to a specific focus (a product, a consumption experience, salesperson, surprise, outcomes ...) that occurs at a certain time (post purchase, post-choice, during consumption, after analysis of accumulated experience ...). A brief example may illustrate the tremendous and clear divergences in the diverse satisfaction conceptualizations. Oliver for instance from 1981 to 1997 has developed a multiplicity of definitions, while in some studies he considered consumer satisfaction as an attitude that occurs after consumption (Mano and Oliver, 1993) [6], in others, it was defined as a summary attribute coexisting with a set of consumption emotions that occur during consumption (Oliver, 1992) [7] or "an evaluation of the surprise inherent in a product acquisition and/or consumption experience" (Oliver, 1981) [8] or simply "a post-choice evaluation judgment" (Westbrook and Oliver, 1991) [9]. A second debate can be noticed in the satisfaction literature, a debate related to its nature. In fact, while some researchers (Westbrook and Reilly, 1983; Halstead, Hartman and Schmidt, 1994 ...) [10] [11] emphasize its emotional and affective aspects and insist on its pure irrational mechanism, others (Howard and Sheth, 1969; Oliver, 1981; Day, 1984; Tse and Wilton, 1988; Mano and Oliver, 1993 ...) [6] [9] [12] [13] argue that consumer satisfaction is a pure cognitive concept that is grounded on a rational and conscious assessment of a certain discrepancy between what was expected and what was really got. Moreover, other researchers (Cadotte, Woodruff and Jenkins, 1987; Swan, Trawick and Carroll, 1981 ...) [14] [15] prefer a mixed conceptualization where both cognitive and affective aspects coexist in the satisfaction definition, thus, the latter is seen as "a conscious evaluation or cognitive judgment that the product has performed relatively well or poorly or that the product was suitable or unsuitable for its use/purpose. Another dimension of satisfaction involves affect or feelings toward the product" (Swan, Trawick and Caroll, 1981, p17). It is to notice also that in some empirical studies, a conative aspect or dimension of satisfaction has emerged (Westbrook and Oliver, 1991). As a result of the absence of a universal definition on one hand and the absence of a consensus regarding its nature on the other hand, the satisfaction literature suffers from a lack of measurement standardization which deepens the problem of generalization and limits comparison. In sum, according to many researchers (Churchill 1979; Gerbing and Anderson, 1988; Bollen, 1989; 
Giese and Cote, 2000) [16] [17] [18], the development of the most appropriate measures as well as valid and reliable results start compulsory by the definition of "the construct's theoretical meaning and conceptual domain" (Giese and Cote, 2000, p2). Based upon this view, in the study in hand, consumer satisfaction is defined as "a post-consumption affective and conscious response based on the product experience consumption and its performance”.

\subsection{Brand Attachment}

The concept of attachment as many relational concepts used in marketing research finds its sources in the interpersonal psychology, the first studies focused on the relationship mother-child as a compulsory base "to grow up mentally healthy" (Bowbly, 1951, p765) [19], love relationships (Hazan and Shaver, 1994) [20], and friendship links (Weis, 1988; Trinke and Bartholomev, 1997) [21] [22]. Ties characterized by feelings of affiliation and proximity that can be transferred according to many psychologists and researchers (Csikszentmihlyi and Rochberg Halton, 1981; Belk, 1992; Richins, 1994) [23] [24] [25] to materials and objects.

In fact, according to Bowlby (1969), the physical objects aid in the identity formation especially when children become independent and separated from their mothers. This delicate and deep bond continues and lasts for a lifetime, some psychologists bent over adolescent-objects relationship, it was demonstrated through researches that at that particular age, adolescents experience an "Identity Crisis" which drives them to seek identity through acquiring and accumulating material objects.

In sum, attachment highlights the ability of tangible objects to reflect and reinforce the identity of the buyer and even to reach an ideal self (Belk, 1988; McCracken, 1986; Wallendorf and Arnould, 1988; Babin et al., 1995) [26] [27] [28] [29].

It was in the nineties that the concept of attachment was finally transposed to brands in the nineties when the number of research on brand equity and consumer-brand relationship has captured the spot light. Brand attachment (BA) is in fact a crucial and essential concept in explaining the type and the depth of the relationship customer-brand, not only, for scholars but also, for practitioners and managers who endeavor to restrain their customers in a market characterized by fierce competition and mass communication. Several definitions of attachment have been suggested and they have all emphasized its psychological, emotional and affective components. According to Cristau (2001, p13) [30], BA "is an enduring psychological, emotional and interactive relationship between the customer and the brand where the affective grade is expressed by dependence and friendship characteristics". This definition stresses on the emotional aspect and conceptualizes attachment as the simultaneous conjunction of dependence (the customer relies on the brand to fulfill his/her requirements, needs, desires and to carry out their expectations) and friendship (mutual concessions, give and take, sacrifices to satisfy the partner and shared benefits). 
Heilbrunn (2001, p10) [31] defines BA as "the intensity of the emotional and the affective link between customer and brand", this definition is based on a transposition of the interpersonal attachment in social psychology to the world of brands. Furthermore, Lacoeuilhe (2000) [32] posits that attachment is an inalienable affective and psychological variable that is independent of both the purchase context and the brand's extrinsic or intrinsic features.

Increased number of studies has focused on the determinants of brand attachment. In fact, according to Lacoeiulhe (2000), two main antecedents can be identified. On one hand, nostalgia referring to the role that brands play as "story of life", a possession that record the different phases of one's life. In the words of A. Kenneth $(1984$, p144) [26] "In later years the object would serve to remind its owners of the day it first entered their home and of the time that had passed since then. It would not only structure their present but also their perceptions of their own past". On the other hand, image congruence where brands are considered as a means of communication that customers use to broadcast their self-image that they really have or desire to hold. In other terms, when a consumer purchases a brand and is highly attached to it, this means that it encompasses an image and has a set of values that $\mathrm{s} / \mathrm{he}$ endeavors to own in order "to transform them in their own eyes and in the eyes of others" (Ames, 1984, p145) [33]. In short, in an emphasis of this brand congruence and identification or the "for me" evaluation Plummer $(1985$, p29) [34] posits that "the consumer who favors or uses any particular brand most often has looked at all this information and communication (...) and somewhere inside his or her head he or she has said, I see myself in that brand, or I see that brand in myself".

Other research, like the Smaoui's (2008) [35] one, have classified the attachment determinants in two categories. A first group called "Relational Variables Customer-Brand" that embodies all the concepts that describe an enduring and deep brand-customer relationship such as nostalgic connections, brand trust, satisfaction and the brand-customer congruence. A second group named "Product Related Variables" that explains the brand attachment by objective motives such as the brand country of origin and the product involvement as well as the product category.

\subsection{Brand Trust}

One of the most important concepts used to examine the depth of brand-individual relationship is brand trust that gained a great interest among marketing scholars. This can be explained by the evolving number of crisis and unethical practices used by some firms as well as the importance of confidence in warranting the exchange's stability (Gatfaoui and Lavorata, 2001) [36], reducing the doubt in volatile environment (Chaudhuri and Holbrook, 2001) [37] and securing clients (Georges and Decock Good, 2004) [38]. In this regard, Bainbridge (1997, p13) [39] asserted that "a trustworthy brand places the consumer at the center of its world and relies more on understanding real consumer 
needs and fulfilling them than the particular service or product. It is not merely responsive, but responsible".

According to Romaniuk and Bogomolova (2005) [40], trust is a "hygiene" factor that all the competing brands must possess in order to be more competitive. It is a positive reputation validated by a third party in a long-term relationship (Bloy, 1996) [41]. Trust exits "when one party has confidence in an exchange partner's reliability and integrity" (Morgan and Hunt, 1994, p23) [42]. BT refers to the ability of the brand to satisfy all the customer's requirements and to live up to any promises. BT has been defined as "the willingness of the average consumer to rely on the ability of the brand to perform its stated function" (Chaudhuri and Holbrook, 2001, p13, 14), as "a feeling security held by the consumer in his/her interaction with the brand, that it is based on the perceptions that the brand is reliable and responsible for the interests and welfare of the consumer". (Ballester and Munuera Aleman, 2002, p12) [43] or simply as "the presumption that the brand, as a personified entity, commits itself to produce a predictable reaction (behavior) consistent with the customer's expectations and to support this orientation in the future with benevolence" (Gurviez, 1999, p20). [44].

An important question that many scholars and practitioners have addressed is how to build up consumer confidence? In fact, the literature review reveals two main categories of BT antecedents. The first group is based on rational drivers grounded on the brand competence, its reputation, its willingness to keep its promises, its ability to raise up the customer pleasure and comfort, to satisfy them, to keep in pace with their evolving requirements and to reassure them by controlling the sources of the brand's perceived risk. In fact, Blomqvist, Ballester and Aleman (2000) [39] have postulated that the main condition of the creation of the brand trust is the perceived risk, its depth and nature; the more the risk is present, the more the development of the confidence feeling is hard and unexpected. The second category of BT antecedents is composed of factors signaling perceived common points between the consumer and his/her brand. In this case, the customer does not rely on the skills and the efficiency of the brand but seeks for shared values and the extent to which the brand is able to meet his/her expectations and evolving needs. In this regard, Morgan and Hunt (1994) have proposed the following determinants: First, the shared values that suppose the existence of some beliefs and convictions that the different exchange or relationship partners do have in common. In other words, Gurviez (1999) declared that the trust is attributed to a brand when this latter holds a set of values that the customer considers as theirs. Second, the perceived enduring communication that can be translated through assistance, resolution of the brand-customer problems and troubles that may occur at any phase of this tie, empathy as well as the care and the continuous listening of the personnel. Third, the previous experience that refers to the existence of a series of positive experiences and encounters between the customer and the brand. Finally, the faith in the brand which is extremely important especially when certain adjustments of the actual brand's 
traits are to be undertaken (Rekom, Jacobs and Verlegh, 2006) [45], and also in the case of brand stretching.

\subsection{Brand Loyalty}

Developing and maintaining a strong consumer-brand relationship is the only guarantee to survive in competitive, turbulent and borderless markets where consumers become more and more powerful, demanding and hard to please because of the variety of brands and alternatives, brand loyalty is one of the most important weapons that marketing managers should focus on in order to thrive and stand in the crowd. Moreover, loyalty helps them increase their market shares and conquer new clients, in fact, loyal customers are true ambassadors of their preferred and favorite brand, they vouch it and encourage their surroundings to get it through many techniques. This concept hasn't only attracted marketing practitioners but also a lot of scholars and researchers worldwide. When reviewing the huge number of research and studies that have examined the concept of brand loyalty, one can notice that there is no consensus concerning its definition. In fact, many conceptualizations have been developed each one from a different angle, however, three main approaches may be mentioned: behaviorist one (linking loyalty to repeat buying behavior) and attitudinal one (linking loyalty to emotions and positive attitude towards the brand) and finally the composite one that consider loyalty as a mixture of emotions and behavior.

\subsubsection{The Behavioral Approach}

In the early literature, brand loyalty first emerged in the marketing literature as a repeat purchasing behavior and a strong preference to a given brand. Later in 1952, Brown [46] included past behavior as an indicator of loyalty. Furthermore, Sheth (1968) [47] considered brand loyalty "a function of a brand's relative frequency purchases in time-independent situations and it's a function of relative frequency and purchase pattern in time-dependent situations". According to Bei and Chiao (2008, p3) [48] and in a modification of Oliver's definition (1997) [49], loyalty is considered as "a deeply held commitment to repeat purchases of a preferred product or service consistently in the future, despite situational influences and marketing efforts having the potential to cause switching behavior". Briefly, according to behaviorist researchers, to be qualified as loyal, the customer must rebuy the given brand whatever is his /her motivation (emotional or habit). In fact, "the extent of purchase at a certain time or the frequency of purchase during a certain period of time" (Sheth, 1968), the share of wallet and the word-of-mouth referrals are the main indicators of loyalty.

This approach that limits loyalty to mere repetitive purchase without a clear conceptual distinction between meaningless repurchase based on simple habits and deep loyalty based on conviction and attitude and emotional attachment (Morgan et Hunt, 1994) and focuses on the description and prediction of consumer behavior was enormously criticized. Hence, new conceptualization of brand loyalty, emphasizing emotions, strong commitment and positive attitude 
towards the brand emerged in the marketing literature. According to Oliver (1999), the problem of this conceptualization is that it does not "tap into the psychological meaning of ... Loyalty" (Oliver, 1999, p34).

\subsubsection{The Attitudinal Approach}

Given the aforementioned limits of the behavioral approach of loyalty, many scholars have questioned the sufficiency of the use of the observed repurchase behavior as the sole indicator of loyalty and suggested the attitudinal approach that "consists of criteria like commitment, trust or emotional attachment". Day in 1969 [50] criticized this behavioral conceptualization and argued that "brand loyalty develops as a result of a conscious effort to evaluate competing brands" in fact, contrary to the first approach, a loyal customer does not necessarily repurchase the given brand but should have positive and strong beliefs and feelings toward it among a set of competing brands (Dick \& Basu, 1994) [51] that are "expressed mainly by brand preference or a psychological predisposition" towards it.

Based on this attitudinal perspective, brand loyalty was defined as "the behavioral response expressed over time by some decision-making unit, with respect to one or more alternative brands out of a set of such brands, and is a function of psychological processes" (Jacoby and Chestnut, 1978, p11) [52].

Through extensive research, Baldinger and Rubinson (1996) [53] have validated that highly loyal buyers are those whose attitudes towards a brand are positive. In addition, in an extremely competitive market, "the ability to convert a switching buyer into a loyal buyer is much higher if the buyer has a favorable attitude toward the brand". From this attitudinal angle, brand loyalty is measured through attitude or/and preferences or/and future behavior intentions scales (Louis-Lombart 2007) [54].

This new orientation in the examination and the analysis of the loyalty concept has the merit that it focuses on loyalty's motives and not its mere manifestation (repurchase). In other terms, it emphasizes the role of motivations, attitudes and preferences as indicators of consumer loyalty. Albeit its real contribution to a deeper understanding of loyalty as attitude and psychologically grounded concept not as routinized purchase and behavior, this approach was criticized as it considers the attitude the only indicator of loyalty which puts in dark other factors and antecedents able to explain the effective re-buying behavior. Since then, scholars started to consider loyalty phenomenon as a conjunction of attitude and behavior.

\subsubsection{The Composite Approach}

Given the limits of the two aforementioned approaches, many researchers argue that brand loyalty is composed of mainly two dimensions: behavior and attitude. In fact, a loyal customer is the one who expresses his/her positive attitude and preference toward the given brand (the psychological and emotional side of loyalty) through consistent purchase and other practices such as the word-of-mouth referrals (the behavioral side of loyalty). For instance, Jacoby 
(1971) [55] defined brand loyalty as "an effective buying behaviour of a particular brand, repeated over time, and reinforced with a strong commitment to that brand", similarly to other conceptualizations (Gremler and Brown 1998; Mellens, Dekimpe and Steenkampe 1996; Touzani and Temessek, 2009) [56] [57] [58], this definition includes commitment as a key factor for a better understanding of loyalty. Following the same wave of research, Touzani and Temessek (2009), brand loyalty is seen as "the degree to which a consumer is committed to a given brand and exhibits a repeat purchasing behaviour towards the same brand". Supporting this composite perspective, Oliver (1999) defined brand loyalty as "a deeply held commitment to rebuy or repatronize a preferred product/service consistently in the future, thereby causing repetitive same-brand or same brand-set purchasing, despite situational influences and marketing efforts having the potential to cause switching behavior".

Adhering to this approach, Dick and Basu (1994) [59] have proposed four types of brand loyalty: "True loyalty", no loyalty, spurious loyalty and latent loyalty as presented in Table 1 .

True loyalty: The consumer's positive attitude and strong preference towards the given brand are linked to high and continuous purchase behavior, this loyalty is qualified as "true loyalty".

Latent loyalty: Despite positive and strong beliefs toward the given brand, the customer does not re-buy frequently the given brand. This can be explained by financial factors, by the non-availability of the preferred brand at the right place.

Spurious loyalty: The customer purchases frequently the given brand without being aware or assessing its distinctive characteristics. In fact, the re-buying is no more than a simple habit that is not grounded on preference and positive attitude; the customer has no interest in the brand and other factors lead to this repetitive purchase behavior.

No loyalty: The competing brands are seen as similar, the customer cannot communicate particular advantages of the given brand, s/he may have a positive orientation towards another brand, they can be "neutral and uninterested" or used to be loyal and ceased to do so .... Many factors can explain the behavior of non-loyal customers.

This composite approach has the merit that it gives the most robust and reliable measures of brand loyalty contrary to the sole frequency of purchase (behavioral approach) or the mere brand preference (attitudinal approach). Moreover, it allows a better understanding of the complex nature of loyalty by taking into consideration many of its aspects (psychological and rational).

Table 1. Attitude/behavior based loyalty.

\begin{tabular}{cccc}
\hline & & \multicolumn{2}{c}{ Repeat patronage } \\
\hline & & High & Low \\
\hline \multirow{2}{*}{ Relative attitude } & High & Loyalty & Latent loyalty \\
& Low & Spurious loyalty & No loyalty \\
\hline
\end{tabular}


In conclusion and according to Knox and Walker's (2001) [60], brand loyalty can be considered as a set of six necessary and sufficient conditions which are:

1) Biased (i.e. non random).

2) Behavioral response (i.e. purchase).

3) Should be expressed over time.

4) By some decision-making unit.

5) With respect to one or more alternative brands out of a set of such brands.

6) A function of psychological (decision making, evaluative) processes (Jacoby and Chestnut, 1978. p. 80) [52].

Figure 1 summarizes the different conceptualizations of brand loyalty in the marketing literature.

\section{The Empirical Part}

\subsection{The Research Problem and Objectives}

Extensive research has been devoted to examining the consumer satisfaction consequences but few studies were concerned with the analysis of its impact on the consumer-retailer brands relationship as well as its role in establishing and increasing store loyalty. Consequently, the overall objective of the research in hand is to fill in this gap and examine on one hand the consumer satisfaction effect on the consumer-retailer brands bond through its impact on attachment and trust and on the other hand the role of this tie in increasing the cognitive, affective, conative and behavioral store loyalty as well as the study of the direct effect of satisfaction on this fidelity.

\subsection{The Conceptual Model and the Research Hypotheses}

\subsubsection{Research Hypotheses}

According to Najjar and Zaiem (2011), satisfaction and brand trust are so important and vital concepts that allow the implementation of marketing strategies that facilitate the development and the maintaining of a long-lasting and a win-win consumer-brand relationship. Moreover, several studies reported that consumer satisfaction leads directly to brand trust (Najjar and Zaiem, 2011; Dixon et al., 2005; Chumpitaz and Paparoidamis, 2007; Sirieix and Dubois, 1999) [61] [62] [63]. In fact, in a Tunisian context, Najjar and Zaiem's (2011) study brought support to the abundant studies that have demonstrated this causal link and indicated hence that "trust constitutes a crucial satisfaction consequence in the relational paradigm" (Najjar and Zaiem, 2011, p3). Consistent with prior research, the following hypothesis is formulated:

H1: Consumer satisfaction with Private Labels has a direct significant statistical impact on trust toward them.

The extant literature reports that consumer satisfaction has a significant and positive impact on brand attachment (Aurier et al., 2001; Thomson et al., 2005; Smaoui, 2008) [64] [65]. However, the linkage is still controversed. In fact, while some researchers consider satisfaction a direct antecedent of attachment (Smaoui, 2008) and assert that "the consumer who is attached to a brand is 


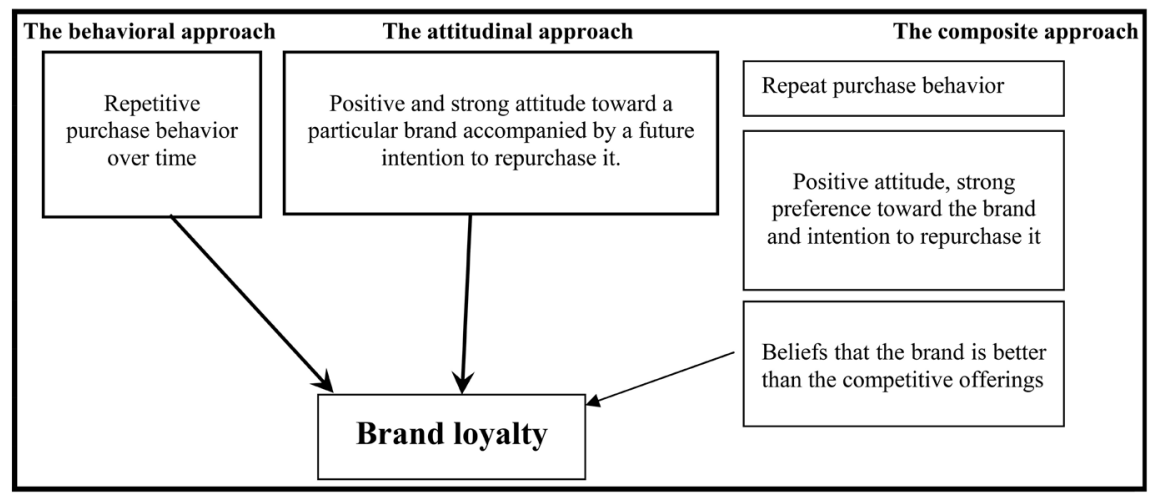

Figure 1. The three approaches of brand loyalty.

generally satisfied with it", others posited that satisfaction exhibits an indirect effect on brand attachment through confidence. In this study, both direct and indirect effects are to be examined. The impact of trust on attachment is indicated by a dotted line in the conceptual model.

H2: Consumer satisfaction with Private Labels has a direct significant statistical impact on brand attachment.

By analyzing the literature, it comes to light another significant relationship between a trilogy of concepts that lead directly to loyalty namely trust, attachment and commitment. In fact, according to Gouteron (2008) [66], the more the consumer trusts a brand, the more he feels attached to it. In the same stream, several studies proved that trust precedes attachment (Ayoubi, 2016; Fournier 1998; Aurier et al. 2001; Chaudhuri \& Holbrook, 2001 ...) [67] [68]. Garbarino and Johnson (1999) [69] as well as Morgan and Hunt (1994) have highlighted the impact of trust on attachment on the long-term. Aurier et al. (2001) and in their "relational chain" aiming the comprehension of loyalty: Quality $\rightarrow$ Value $\rightarrow$ Satisfaction $\rightarrow$ Trust $\rightarrow$ Attachment highlighted that trust is an antecedent of attachment. A presumption was accepted and adopted by Smaoui (2008) in her work on attachment determinants.

H3: Brand trust has a direct significant statistical impact on brand attachment.

Brand attachment, a concept that refers to a certain psychological and emotional proximity between the consumer and the brand (Lacoeuilhe, 2000; Heilbrunn, 2001; Cristau, 2001) has attracted a lot of researchers since a long time given its importance in the creation of an enduring consumer-brand tie. Several studies (Day, 1969; Dick \& Basu, 1994; Sirieix \& Dubois, 1999; Gurviez, 1999; Lacoeuilhe, 2000; Aurier et al., 2001, Ambroise et al., 2007) [70] showed that brand attachment is an important antecedent of loyalty both its attitudinal dimension and behavioral one. Similarly, Chaudhuri \& Holbrook $(2001,2002)$ argued that loyalty is the result of a relational process that goes from attachment to trust where this latter seems to play a mediating role between attachment and loyalty. Hence, this study assumes that:

H4: Consumer satisfaction with Private Labels has indirect significant sta- 
tistical impact on brand loyalty as mediated by brand attachment.

Brand trust is one of the key factors in explaining a long-term consumer-brand relationship as well as attitudinal and behavioral loyalty, it is considered as "the basis of loyalty" (Keller and Berry, 2003) [71], and "fundamental to the development of loyalty" and "is positively related to both purchase loyalty and attitudinal loyalty" (Reicheld and Schefter, 2000; Urban, Sultan \& Quallis, 2000; Gommans et al., 2001) [72] [73] [74]. It is also among its direct antecedents (Singh and Sirdeshmukh, 2000) [75]. Furthermore, trust is viewed as the fundamental ingredient of loyalty, Reicheld and Schefter (2000) observed that "[to] gain the loyalty of customers, you must first gain their trust." Consistent with prior research, this study assumes that:

H5: Consumer satisfaction with Private Labels has indirect significant statistical impact on brand loyalty as mediated by brand trust.

Increasingly number of studies has focused on the satisfaction-loyalty relationship. In fact, several researchers have posited that a loyal customer is always a satisfied one (Anderson et al., 1993; Oliver, 1999; Simon, 2000; Bei and Chiao, 2001; Ladhari, 2005) [76] [77]. Moreover, when brand attachment is high, consumers are willing to make sacrifices and extra personal investment in order to move on and evolve this relationship. In other terms, the consumer's high satisfaction can be mirrored in their stronger repeat purchase behavior that is "accompanied with more willingness to display, defend or recommend" it to their friends and accountancies (Whan Park, Macinnis and Priester, 2006) [78]. In short, the preceding studies that have examined the satisfaction-loyalty linkage have reported that consumer satisfaction exhibits a strong, a positive and a significant impact on brand loyalty. This research proposes the analysis of the impact of consumer satisfaction with retailer brands on the store loyalty, thus the sixth hypothesis is formulated as follow:

H6: Consumer satisfaction with Private Labels has direct significant statistical impact on store loyalty.

\subsubsection{Research Proposed Conceptual Model}

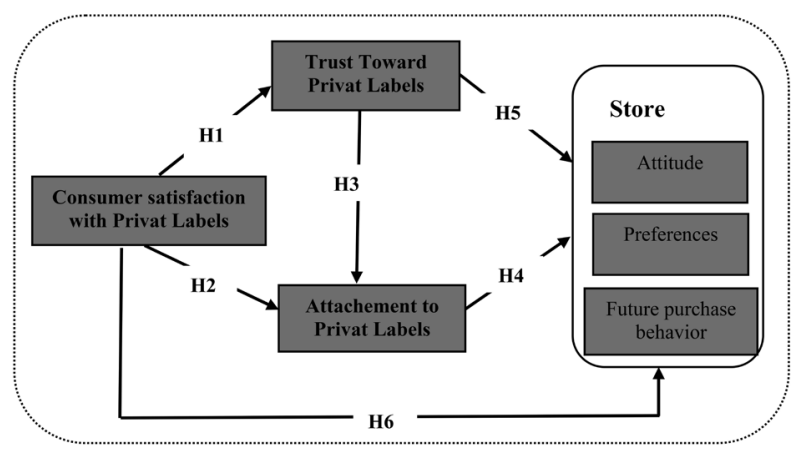

Figure 2. Research model.

\subsection{Methodology}

The data of the precedent collection was firstly seized and analyzed through a 
Principal Component Analysis (SPSS 17) in order to gather the diverse candidate personality traits and classify them under different dimensions. Then, the reliability of the generated scales (two for every type of brand) was estimated through the Cronbach's Alpha that allows the evaluation of the internal coherence over and above the homogeneity of a set of items. Finally, the estimation of the convergent and discriminating validities was established.

After having compared the different scales that were developed in the francophone context, the unidimensional scale of Lacoeuilhe $(2000)^{1}$ will be used in this research. thanks to the consistency that it proved when used in many studies such as in Gouteron $(2006)^{2}$ article, in Smaoui $(2008)^{3}$ and many other researches as well as its reliability that was calculated by both the Cronbach's Alpha (0.830) and the $\rho$ de Joreskog (0.890).

The scale of Gurviez, Korchia (2002) ${ }^{4}$ with eight items will be used in the current research; this conception presents Brand Trust as a tridimensional construct composed of 8 items distributed upon the three factors as follows:

As it is impossible to get a nominative and exhaustive list of all the Retailer Brands consumers, the research will spread on area of the Big Tunis. In the current research, the mother population is composed of all the consumers of the Retailer Brands in Tunisia.

In order to provide more accurate findings, the survey took place in the stores that are broadcasting their own brands such as Carrefour, Bonprix, Géant, Champion Tunis and Champion Boumhel. The survey was administrated to a convenience sample of men and women who filled in 256 questionnaires by tapping their perceptions of Retailer brands personality and expressing their attachment and trust levels towards them. A part of the questionnaires was conferred to some pollsters or poll takers after having explained the subject of the research and gave them the tips to follow and respect during the interviews.

\section{Analysis and Findings}

\subsection{Data Analysis}

Partial least squares (PLS) were chosen for the current study by using (SmartPLS 3) software. It was used in a two-stage approach, measurement and structural model testing.

\subsubsection{Measurement Model}

The measurement model can be assessed by examining the reliability, convergent validity and discriminant validity. Specifically, reliability which refers to the ${ }^{1}$ Lacoeuilhe J. (2000), "L'attachement à la marque: proposition d'une échelle de mesure" Recherche et Applications en Marketing, Vol15, No 4, 61-77.

${ }^{2}$ Gouteron. J. (2006): “L'impact de la personnalité de la marque sur la relation marque-consommateur: Application au marché du prêt-à-porter féminin”. Revue Française du Marketing; No222, 43-59.

${ }^{3}$ Smaoui . F. (2008): "Les déterminants de l'attachement émotionel à la marque: Effets des variables relationnelles et des variables relatives au produit" 7ème Congrès des Tendances Marketing, Venise 17-18 Janvier 2008.

${ }^{4}$ Gurviez P and Korchia M (2002): "Proposition d'une échelle de mesure multidimensionnelle de la confiance dans la marque”. Recherche et Application en Marketing, vol17, 3, 41-62. 
internal consistency of measurement, can be assessed by checking if the value of composite reliability $(\mathrm{CR})$ is more than 0.7 , the average variance extracted (AVE) is greater than 0.5 and Cronbach's $\alpha$ is greater than 0.6 (Hair et al., 2006). Table 2 shows that the CR values ranged from 0.87 to 0.92 and the AVE values ranged from 0.53 to 0.69 . These values are higher than the acceptance value 0.50 which indicate a good construct reliability. Furthermore, in order to check the convergent validity, loading factor for each item was calculated. All item loadings are larger than 0.6 , which indicates that the scale has a good convergent validity. Furthermore, the Cronbach's $\alpha$ values for all research variables are greater than (0.70) which high accepted value (Hair et al., 2006).

Bootstrapping method in Smart LS software was used to test the statistical significance of path coefficients. Figure 2 shows the $\mathrm{P}$ value for all research variables and the PLS model of the study.

Table 2. Result of construct assessment.

\begin{tabular}{|c|c|c|c|c|c|c|c|}
\hline Constructs & Items & Factor loading & Mean & SD & CR & Cronbach's $\alpha$ & AVE \\
\hline \multirow{4}{*}{$\begin{array}{c}\text { Consumer } \\
\text { satisfaction } \\
\text { with Private } \\
\text { Labels }\end{array}$} & Sat1 & 0.845 & 3.835 & 0.862 & \multirow{4}{*}{0.881} & \multirow{4}{*}{0.817} & \multirow{4}{*}{0.650} \\
\hline & Sat2 & 0.781 & 3.54 & 0.833 & & & \\
\hline & Sat3 & 0.891 & 3.683 & 0.831 & & & \\
\hline & Sat4 & 0.725 & 3.353 & 1.01 & & & \\
\hline \multirow{6}{*}{ Brand trust } & BT1 & 0.753 & 3.727 & 0.855 & \multirow{6}{*}{0.875} & \multirow{6}{*}{0.830} & \multirow{6}{*}{0.539} \\
\hline & BT2 & 0.772 & 3.54 & 0.998 & & & \\
\hline & BT3 & 0.709 & 3.266 & 0.941 & & & \\
\hline & BT4 & 0.757 & 3.54 & 0.867 & & & \\
\hline & BT5 & 0.71 & 3.468 & 0.859 & & & \\
\hline & BT6 & 0.761 & 3.504 & 0.781 & & & \\
\hline \multirow{5}{*}{$\begin{array}{c}\text { brand } \\
\text { Attachment }\end{array}$} & BA1 & 0.788 & 3.072 & 1.008 & \multirow{5}{*}{0.919} & \multirow{5}{*}{0.890} & \multirow{5}{*}{0.695} \\
\hline & BA2 & 0.802 & 3.259 & 1.02 & & & \\
\hline & BA3 & 0.909 & 2.892 & 1.091 & & & \\
\hline & BA4 & 0.882 & 2.849 & 0.989 & & & \\
\hline & BA5 & 0.780 & 2.755 & 1.051 & & & \\
\hline \multirow{8}{*}{$\begin{array}{l}\text { Brand } \\
\text { Loyalty }\end{array}$} & BL1 & 0.802 & 3.835 & 0.949 & \multirow{8}{*}{0.927} & \multirow{8}{*}{0.910} & \multirow{8}{*}{0.615} \\
\hline & BL2 & 0.794 & 3.612 & 1.184 & & & \\
\hline & BL3 & 0.814 & 3.748 & 1.039 & & & \\
\hline & BL4 & 0.817 & 3.842 & 0.833 & & & \\
\hline & BL5 & 0.846 & 3.784 & 0.871 & & & \\
\hline & BL6 & 0.702 & 3.439 & 1.047 & & & \\
\hline & BL7 & 0.811 & 3.58 & 1.125 & & & \\
\hline & BL8 & 0.711 & 3.81 & 1.05 & & & \\
\hline
\end{tabular}




\subsubsection{Structural Model}

The outcome presented in Figure 3 and Table 3 provided support for the research hypotheses. A detailed information and direction of the hypotheses will be discussed in the following paragraphs.

The analysis result reveals that the factor (Consumer satisfaction with Private Labels) has direct significant impact on brand trust ( $\mathrm{p} \leq 0.05)$ which lead to accept and support H1. As well as, Consumer satisfaction with Private Labels explain around $58 \%$ of brand trust variance.

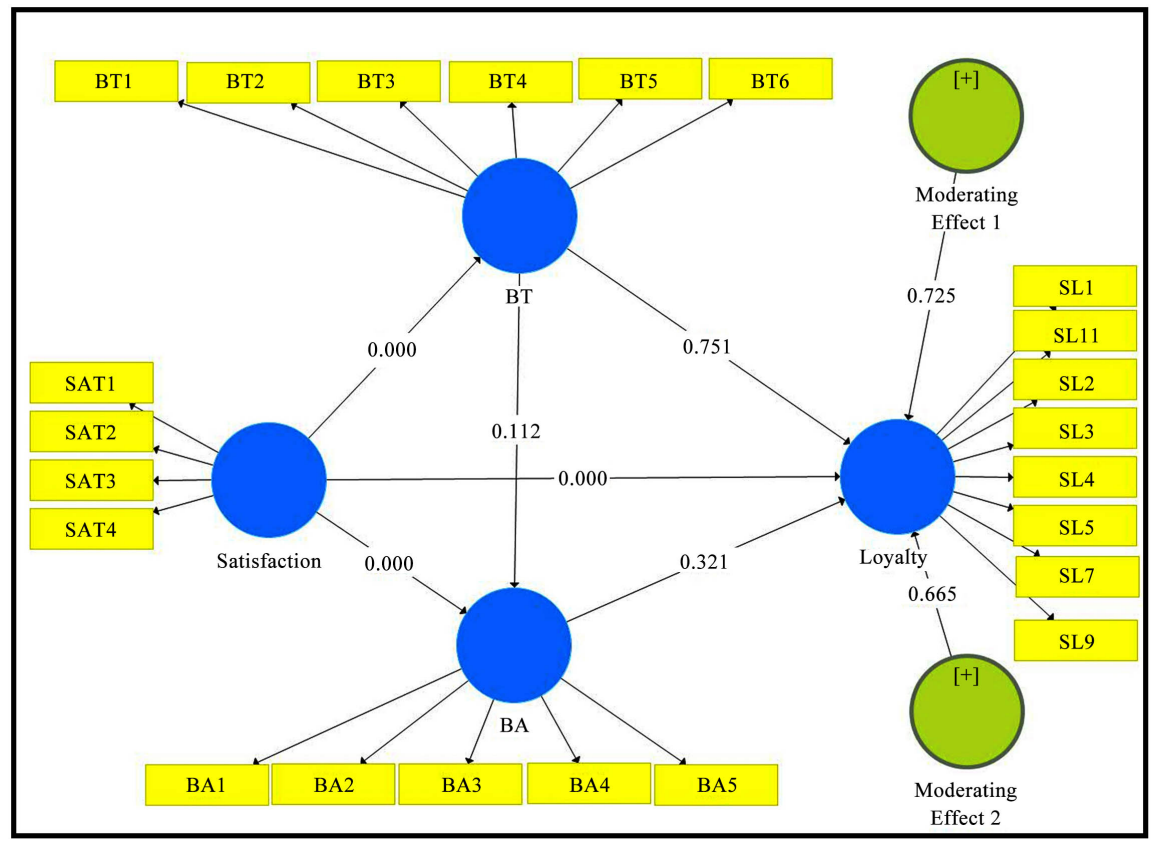

Figure 3. Results of PLS.

Table 3. Summary of hypothesis testing results.

\begin{tabular}{|c|c|c|c|c|c|}
\hline NO & Path (hypothesis) & $\begin{array}{l}\text { Standard } \\
\text { Deviation }\end{array}$ & $\begin{array}{l}\mathrm{T} \\
\text { Statistics }\end{array}$ & $\begin{array}{l}P \\
\text { Values }\end{array}$ & Result \\
\hline 1 & $\begin{array}{l}\text { H1: Consumer satisfaction with Private Labels } \\
\text { has a direct significant statistical impact on trust } \\
\text { toward them. }\end{array}$ & 0.047 & 13.436 & 0.000 & Supported \\
\hline 2 & $\begin{array}{l}\text { H2: Consumer satisfaction with Private Labels } \\
\text { has a direct significant statistical impact on brand } \\
\text { attachment. }\end{array}$ & 0.096 & 4.242 & 0.000 & Supported \\
\hline 3 & $\begin{array}{l}\text { H3: Brand trust has a direct significant statistical } \\
\text { impact on brand attachment. }\end{array}$ & 0.094 & 1.590 & 0.112 & Not \\
\hline 4 & $\begin{array}{l}\text { H4: Consumer satisfaction with Private Labels } \\
\text { has indirect significant statistical impact on brand } \\
\text { loyalty as mediated by brand attachment. }\end{array}$ & 0.104 & 0.337 & 0.736 & Not \\
\hline 5 & $\begin{array}{l}\text { H5: Consumer satisfaction with Private Labels } \\
\text { has indirect significant statistical impact on brand } \\
\text { loyalty as mediated by brand trust. }\end{array}$ & 0.089 & 0.435 & 0.664 & Not \\
\hline 6 & $\begin{array}{l}\text { H6: Consumer satisfaction with Private Labels } \\
\text { has direct significant statistical impact on store } \\
\text { loyalty. }\end{array}$ & 0.105 & 5.116 & 0.000 & Supported \\
\hline
\end{tabular}


In addition, the result shows that Consumer satisfaction with Private Labels has direct significant impact on brand attachment $(\mathrm{p} \leq 0.05)$ and it explains around $34 \%$ of brand attachment variance. Thus, $\mathrm{H} 2$ is accepted.

On the other hand, the result shows that brand trust has no influence on brand attachment directly ( $\mathrm{p} \geq 0.05$ ) which lead to reject $\mathrm{H} 3$.

Furthermore, the mediating impact of brand attachment and brand trust between Consumer satisfaction with Private Labels and brand loyalty was not influence, which lead to reject and not support $\mathrm{H} 4$ and $\mathrm{H} 5$.

Finally, the result supports the direct impact of Consumer satisfaction with Private Labels on brand loyalty $(\mathrm{p} \leq 0.05)$ and it explains around $43 \%$ of brand loyalty variance. Thus, H6 is accepted.

The outcome presented in Table 4 provided support for the research hypotheses. Detailed information and results of the hypotheses will be shown in the following table.

Moreover, the goodness of fit index (GFI) is a measure of fit between the hypothesized model and the observed covariance matrix. The normed fit index (NFI) is the discrepancy between the chi-squared value of the hypothesized model and the chi-squared value of the null model. Comparative fit index (CFI) is equal to the discrepancy function adjusted for sample size. The root mean square residual (RMR), is the square root of the discrepancy between the sample covariance matrix and the model covariance matrix. In addition, Incremental fit index (IFI) and The Tucker-Lewis coefficient (TLI) were evaluated.

Next, all measures for the measurement models were subjected to CFA to understand the structure and underlying interrelationships of the complex structure. In addition, reliability and validity were also assessed. In Table 1 , the goodness of fit for the study constructs yielded accepted results: CMIN $(\div 2)$ values all had significant $\mathrm{p}$ values, $\mathrm{p}<0.001$, GFI values were closer to 1 , and $1=$ perfect fit, NFI values were closer to 1 , and $1=$ perfect fit, IFI values were closer to 1 , and 1 = perfect fit, TLI values were closer to 1 , and $1=$ perfect fit, CFI values were closer to 1 , and $1=$ perfect fit, $R M R$ values $<0.060$ represent perfect fit, Relative chi-square $(\mathrm{R} . \div 2)$ were values between 1 and 5 are the accepted benchmark used in prior research (Bentler and Bonett, 1980, Bollen, 1989a, Bollen, 1989b, Browne and Cudeck, 1993) [79] [80] [81] [82].

\section{Conclusions}

The study in hand tried to shed light on the relationship between Tunisian consumers and their stores that do have and distribute their owns brands; this relationship analysis was moderated by two important variables in studying relationships in marketing that are brand trust and brand attachment. The research aimed to clarify an infant relationship since Private Labels are not well-known in Tunisia and in many cases they are mentally associated with low quality and as being the last choice in case of non-existence of the favorite brands' products. 
Table 4. Model fit results.

\begin{tabular}{cc}
\hline \multicolumn{1}{c}{ Model Fit statistics } \\
\hline Chi-square & 902.815 \\
Degrees of freedom & 371 \\
Probability level & 0.000 \\
RMR & 0.079 \\
GFI & 0.702 \\
NFI & 0.669 \\
CFI & 0.771 \\
TLI & 0.749 \\
RMSEA & 0.073 \\
\hline
\end{tabular}

Several hypotheses were set to better understand this bond in an exploratory context since no recent studies were available about Tunisians behavior toward retailer brands combining the same factors, so this research is an initiative for establishing a database about Tunisians and Private Labels. A survey took place and more than two hundred consumers were asked to administrate their opinions in 5 Likert scales related to the study's variables. The results show that consumers' satisfaction with Private Labels has a direct significant statistical impact on store loyalty as it was found in previous studies conducted in non-Tunisian context (Aliawadi et al. 2014, and Guenzi et al. 2009) [83] [84]. Also, retailers gain a probability to increase customers' loyalty by having their own private labels (Koschate-Fischer et al. 2014) [85]. Therefore, stores are highly recommended to manage their private labels and their relationships with customers and to monitor them very well. Customers are motivated and affected by their satisfaction with private labels to make repeated purchases from the store and being loyal to it.

The relationship between brand satisfaction with private labels and store loyalty is not affected by the mediating roles of brand attachment neither brand trust; the latter is supported by the study of (Calvo et al. 2016) [86] who found that trust doesn't mediate the relationship between prices of private labels and store loyalty. Also the study goes with Belaid et al. (2011) [87] who found that satisfaction is not always a way to transfer a customer who trusts a brand to a continuous loyal to it. This means that satisfied customers will be attached to the brand but might not be loyal to the store which sells the brand. The same for trust, customer might trust the private brand but this shouldn't lead to store loyalty.

The research didn't statistically support a relationship between brand trust and brand attachment. In fact, since in many studies in sociology, Arab people tend to be affected emotionally by the packaging, the country of origin and other factors and do systematically develop emotions toward those products before even trusting them; hence this can be an explanation of the inexistence of a posi- 
tive impact of brand trust on attachment. Finally, it supported the results of Pandowo (2016) [88] that demonstrated that satisfaction with retailer brands leads to strong emotional attachment toward them.

\section{Research Limitations}

Like every scientific study, the research in hand does have some limitations related first to the sample, it would be bigger which impacts positively many statistical indices in AMOS and the structural equations in general. The number of participants was chosen according to the awareness of Private Labels in Tunisia which is to a certain extent week which puts this research in exploratory context. Next study will use bigger sample since the awareness is improving now in $\mathrm{Tu}$ nisia thanks to the communication strategies of especially Carrefour and Géant that are making the retailers' brands more known.

Second, the survey that took place in a big part of it at Carrefour and Géant and Monoprix those hyper and supermarkets in Tunisia that do have their own brands may be another limitation of the study. In fact, the participants at those places do have many priorities which filling in a questionnaire is considered as a disturbance and a time waste.

Finally, the timing of the research would be a limitation since the Private Labels are not so popular in Tunisia which forced us in many cases to explain the concept and present some examples of them to the participants to better figure out the meaning of the research.

\section{Academic and Professional Implications}

Despite its exploratory aspect, this research does have some implications to the academic world besides the professional field especially retailing.

As it was explained along the article, this study tried to explore an area not covered scientifically in Tunisia, henceforth future Tunisian researchers in marketing can take this study as a basis to understand the nature of the consumer-retailer brands tie and how satisfaction is the first step in building and maintaining it. Whatever is the reason behind the choice and the consumption of the the Private label, being satisfied is the driver of the attitude construction with all its components cognitive, emotional and conative, an attitude that puts the first stone in the bond.

For professionals and marketing managers, the research shows that in the $\mathrm{Tu}$ nisian context where Private Labels are in their childhood and introduction phase of their lifecycle, managers should show up their brands, put in light their distinctive characteristics that in some cases are superior to well known brands. Managers have a hard work in explaining through strong communication campaigns that Private Labels should not be the last choice and that they do not have systematically bad quality (not all the Private Labels are like $\mathrm{N}^{\circ} 1$ of Carrefour that is really low quality). Managers through this research should understand that they should fascinate their customers by the quality of their brands that will lead to satisfaction, re-purchase and relationship development. 


\section{Future Research Recommendations}

This research should give room to future studies in Tunisia that examine the reality of the Private Labels, the challenges and the most appropriate marketing strategies.

$\checkmark$ Future research may focus on the comparison between national and Private Labels in Tunisia to see in depth how Tunisian consumers differentiate mentally and emotionally between their perceived well-known products and those emerging retailers' ones.

$\checkmark$ In this research, we opted for the composite conceptualization of loyalty; future study may focus on the behavioral approach to better understand the realization of satisfaction, trust and attachment seen in the turnover generated by the sale of those brands.

$\checkmark$ Academicians in Tunisia may study the current image of Private Labels after their proliferation and presentation by many retailers now.

$\checkmark$ Future researchers may focus on the commitment to retailer brands, a concept that according to Morgan and Hunt (1994) is considered as the sole measure instrument of the overall marketing strategy.

\section{Conflicts of Interest}

The author declares no conflicts of interest regarding the publication of this paper.

\section{References}

[1] Giese, J.L. and Cote, J.A. (2000) Defining Consumer Satisfaction. Academy of Marketing Science Review, 1, 1-22.

[2] Oliver, R.L. (1999) Whence Consumer Loyalty? Journal of Marketing, 63, 33-44. https://doi.org/10.1177/00222429990634s105

[3] Bei, L.T. and Chiao, Y.C. (2001) An Integrated Model for the Effects of Perceived Product, Perceived Service Quality, and Perceived Price Fairness on Consumer Satisfaction and Loyalty. Journal of Consumer Satisfaction, Dissatisfaction and Complaining Behavior, 14, 125.

[4] Baysinger, B.D., Keim, G.D. and Zeithaml, C.P. (1985) An Empirical Evaluation of the Potential for Including Shareholders in Corporate Constituency Programs. Academy of Management Journal, 28, 180-200. https://doi.org/10.2307/256067

[5] Najjar, H., Najar, C. and Zaiem, I. (2011) Contribution de la qualité relationnelle à la fidélité des consommateurs et au choix du point de vente. Revue Libanaise de Gestion et d Economie, 4, 47-79. https://doi.org/10.1016/S1999-7620(11)70035-0

[6] Mano, H. and Oliver, R.L. (1993) Assessing the Dimensionality and Structure of the Consumption Experience: Evaluation, Feeling, and Satisfaction. Journal of Consumer Research, 20, 451-466. https://doi.org/10.1086/209361

[7] Oliva, T.A., Oliver, R.L. and MacMillan, I.C. (1992) A Catastrophe Model for Developing Service Satisfaction Strategies. Journal of Marketing, 56, 83-95. https://doi.org/10.1177/002224299205600306

[8] Oliver, R.L. and Linda, G. (1981) Effect of Satisfaction and Its Antecedents on Consumer Preference and Intention. In: Monroe, K.B., Ed., Advances in Consumer Re- 
search, Association for Consumer Research, Ann Arbor, 88-93.

[9] Westbrook, R.A. and Oliver, R.L. (1991) The Dimensionality of Consumption Emotion Patterns and Consumer Satisfaction. Journal of Consumer Research, 18, 84-91. https://doi.org/10.1086/209243

[10] Westbrook, R.A. and Reilly, M.D. (1983) Value-Percept Disparity: An Alternative to the Disconfirmation of Expectations Theory of Consumer Satisfaction. In: Bagozzi, R.P. and Tybout, A.M., Eds., Advances in Consumer Research, Association for Consumer Research, Ann Arbor, 256-261.

[11] Halstead, D., Hartman, D. and Schmidt, S.L. (1994) Multisource Effects on the Satisfaction Formation Process. Journal of the Academy of Marketing Science, 22, 114-129. https://doi.org/10.1177/0092070394222002

[12] Howard, J.A. and Sheth, J.N. (1969) The Theory of Buyer Behavior. John Wiley, New York, 63.

[13] Tse, D.K. and Wilton, P.C. (1988) Models of Consumer Satisfaction Formation: An Extension. Journal of Marketing Research, 25, 204-212. https://doi.org/10.1177/002224378802500209

[14] Cadotte, E.R., Woodruff, R.B. and Jenkins, R.L. (1987) Expectations and Norms in Models of Consumer Satisfaction. Journal of Marketing Research, 24, 305-314. https://doi.org/10.1177/002224378702400307

[15] Swan, J.E., Trawick, I.F. and Carroll, M.G. (1981) Effect of Participation in Marketing Research on Consumer Attitudes toward Research and Satisfaction with a Service. Journal of Marketing Research, 18, 356-363. https://doi.org/10.1177/002224378101800309

[16] Churchill Jr., G.A. (1979) A Paradigm for Developing Better Measures of Marketing Constructs. Journal of Marketing Research, 16, 64-73. https://doi.org/10.1177/002224377901600110

[17] Anderson, J.C. and Gerbing, D.W. (1988) Structural Equation Modeling in Practice: A Review and Recommended Two-Step Approach. Psychological Bulletin, 103, 411. https://doi.org/10.1037/0033-2909.103.3.411

[18] Bollen, K.A. (1990) Overall Fit in Covariance Structure Models: Two Types of Sample Size Effects. Psychological Bulletin, 107, 256.

https://doi.org/10.1037/0033-2909.107.2.256

[19] Bowlby, J. (1951) Maternal Care and Mental Health (Vol. 2). World Health Organization, Geneva.

[20] Hazan, C. and Shaver, P.R. (1994) Attachment as an Organizational Framework for Research on Close Relationships. Psychological Inquiry, 5, 1-22. https://doi.org/10.1207/s15327965pli0501_1

[21] Lacoeuilhe, J. (1997) Le concept d'attachement à la marque dans la formation du comportement de fidélité. Revue Française du Marketing, 165, 29-42.

[22] Trinke, S.J. and Bartholomew, K. (1997) Hierarchies of Attachment Relationships in Young Adulthood. Journal of Social and Personal Relationships, 14, 603-625. https://doi.org/10.1177/0265407597145002

[23] Csikszentmihalyi, M. and Halton, E. (1981) The Meaning of Things: Domestic Symbols and the Self. Cambridge University Press, Cambridge. https://doi.org/10.1017/CBO9781139167611

[24] Belk, R.W. (1992) Attachment to Possessions. In: Place Attachment, Springer, Boston, 37-62. https://doi.org/10.1007/978-1-4684-8753-4_3

[25] Richins, M.L. (1994) Special Possessions and the Expression of Material Values. 
Journal of Consumer Research, 21, 522-533. https://doi.org/10.1086/209415

[26] Belk, R.W. (1988) Possessions and the Extended Self. Journal of Consumer Research, 15, 139-168. https://doi.org/10.1086/209154

[27] McCracken, G. (1986) Culture and Consumption: A Theoretical Account of the Structure and Movement of the Cultural Meaning of Consumer Goods. Journal of Consumer Research, 13, 71-84. https://doi.org/10.1086/209048

[28] Wallendorf, M. and Arnould, E.J. (1988) "My Favorite Things": A Cross-Cultural Inquiry into Object Attachment, Possessiveness, and Social Linkage. Journal of Consumer Research, 14, 531-547. https://doi.org/10.1086/209134

[29] Babin, B.J. and Darden, W.R. (1995) Consumer Self-Regulation in a Retail Environment. Journal of Retailing, 71, 47-70. https://doi.org/10.1016/0022-4359(95)90012-8

[30] Cristau, C. (2001) Définition, mesure et modélisation de l'attachement à une marque comme une conjonction de deux dimensions distinctes et concomitantes: La dépendance et l'amitié vis-à-vis de la marque. Papier de Recherche, No. 591, I.A.E Aix-en-Provence.

[31] Heilbrunn, B. (2001) Les facteurs d'attachement du consommateur à la marquee. Doctoral Dissertation, Paris, 9.

[32] Lacoeuilhe, J. (2000) L'attachement à la marque: Proposition d'une échelle de mesure. Recherche et Applications en Marketing, 15, 61-77. https://doi.org/10.1177/076737010001500404

[33] Selfriz, J.J., Duda, J.L. and Chi, L. (1992) The Relationship of Perceived Motivational Climate to Intrinsic Motivation and Beliefs about Success in Basketball. Journal of Sport and Exercise Psychology, 14, 375-391. https://doi.org/10.1123/jsep.14.4.375

[34] Aaker, J.L. (1997) Dimensions of Brand Personality. Journal of Marketing Research, 34, 347-356. https://doi.org/10.1177/002224379703400304

[35] Smaoui, F. (2008) Les déterminants de l'attachement émotionnel à la marque: Effet des variables relationnelles et des variables relatives au produit. Marketing Trends Conference Proceedings, Venice, 17-19 January 2008, 27.

[36] Bonnefont, A. and Lapeyre, A. (2007) Essai de modélisation des perceptions de communication d'enseigne en développement durable par leurs acheteurs: Campagne publicitaire Carrefour 2004. Revue de lorganisation responsable, 2, 20-33. https://doi.org/10.3917/ror.021.0020

[37] Chaudhuri, A. and Holbrook, M.B. (2001) The Chain of Effects from Brand Trust and Brand Affect to Brand Performance: The Role of Brand Loyalty. Journal of Marketing, 65, 81-93. https://doi.org/10.1509/jmkg.65.2.81.18255

[38] Good, C.D. and Georges, L. (2004) Social Practices and Corporate Performance. Studies in Managierial and Financial Accounting, No. 14, 75-96.

[39] Delgado-Ballester, E., Munuera-Aleman, J.L. and Yague-Guillen, M.J. (2003) Development and Validation of a Brand Trust Scale. International Journal of Market Research, 45, 35-54. https://doi.org/10.1177/147078530304500103

[40] Romaniuk, J. and Bogomolova, S. (2005) Variation in Brand Trust Scores. Journal of Targeting, Measurement and Analysis for Marketing, 13, 363-373. https://doi.org/10.1057/palgrave.jt.5740163

[41] Khalifa, A.H. and Kammoun, M.M. (2013) La confiance interpersonnelle et la confiance organisationnelle dans la relation client-prestataire de service: Cas de la relation client-banque. La Revue des Sciences de Gestion, 3, 167-174. https://doi.org/10.3917/rsg.261.0167 
[42] Morgan, R.M. and Hunt, S.D. (1994) The Commitment-Trust Theory of Relationship Marketing. Journal of Marketing, 58, 20-38. https://doi.org/10.1177/002224299405800302

[43] Delgado-Ballester, E. and Munuera-Aleman, J.L. (2002) Development and Validation of a Brand Trust Scale across Product Categories: A Confirmatory and Multigroup Invariance Analysis. Conference Proceedings, 13, 519.

[44] Gurviez, P. and Korchia, M. (2002) Proposition d'une échelle de mesure multidimensionnelle de la confiance dans la marque. Recherche et Applications en Marketing (French Edition), 17, 41-61. https://doi.org/10.1177/076737010201700304

[45] Van Rekom, J., Jacobs, G. and Verlegh, P.W. (2006) Measuring and Managing the Essence of a Brand Personality. Marketing Letters, 17, 181-192.

https://doi.org/10.1007/s11002-006-5362-5

[46] Martin, W.C., Ponder, N. and Lueg, J.E. (2009) Price Fairness Perceptions and Customer Loyalty in a Retail Context. Journal of Business Research, 62, 588-593. https://doi.org/10.1016/j.jbusres.2008.05.017

[47] Sheth, J.N. (1968) A Factor Analytical Model of Brand Loyalty. Journal of Marketing Research, 5, 395-404. https://doi.org/10.1177/002224376800500406

[48] Bakti, I.G.M.Y. and Sumaedi, S. (2013) An Analysis of Library Customer Loyalty: The Role of Service Quality and Customer Satisfaction, a Case Study in Indonesia. Library Management, 34, 397-414.

[49] Oliver, J. (1997) Satisfaction: A Behavioral Perspective on the Consumer. Journal of Consumer Marketing, 14, 401-404.

[50] Sheth, J.N. and Park, C.W. (1974) A Theory of Multidimensional Brand Loyalty. In: Ward, S. and Wright, P., Eds., Advances in Consumer Research, Association for Consumer Research, Ann Arbor, Vol. 1, 449-459.

[51] Dick, A.S. and Basu, K. (1994) Customer Loyalty: Toward an Integrated Conceptual Framework. Journal of the Academy of Marketing Science, 22, 99-113. https://doi.org/10.1177/0092070394222001

[52] Jacoby, J. and Chestnut, R.W. (1978) Brand Loyalty Measurement and Management. John Wiley and Sons, New York.

[53] Baldinger, A.L. and Rubinson, J. (1996) Brand Loyalty: The Link between Attitude and Behavior. Journal of Advertising Research, 36, 22-35.

[54] Louis, D. and Lombard, C. (2007) Impact de la personnalité de la marque sur la satisfaction et la fidélité du consommateur. Papier de recherché, 1-30.

[55] Jacoby, J. (1971) Brand Loyalty: A Conceptual Definition. Proceedings of the Annual Convention of the American Psychological Association, 6 (Pt.2)/1971, 655-656. https://doi.org/10.1037/e611322012-087

[56] Bennett, R. and Bove, L. (2002) Identifying the Key Issues for Measuring Loyalty. Australasian Journal of Market Research, 9, 27-44.

[57] Mellens, M., Dekimpe, M. and Steenkamp, J.B.E.M. (1996) A Review of Brand-Loyalty Measures in Marketing. Tijdschrift voor economie en management, 41, 507-533.

[58] Touzani, M. and Temessek, A. (2009) Brand Loyalty: Impact of Cognitive and Affective Variables. The Annals of Dunarea de Jos University of Galati Fascicle I: Economics and Applied Informatics, 1, 227-242.

[59] Garland, R. and Gendall, P. (2004) Testing Dick and Basu's Customer Loyalty Model. Australasian Marketing Journal, 12, 81-87.

https://doi.org/10.1016/S1441-3582(04)70108-1 
[60] Knox, S. and Walker, D. (2001) Measuring and Managing Brand Loyalty. Journal of Strategic Marketing, 9, 111-128. https://doi.org/10.1080/713775733

[61] Curtis, T., Abratt, R., Rhoades, D.L. and Dion, P. (2011) Customer Loyalty, Repurchase and Satisfaction: A Meta-Analytical Review. Journal of Consumer Satisfaction, Dissatisfaction and Complaining Behavior, 24, 1-26.

[62] Chumpitaz Caceres, R. and Paparoidamis, N.G. (2007) Service Quality, Relationship Satisfaction, Trust, Commitment and Business-to-Business Loyalty. European Journal of Marketing, 41, 836-867. https://doi.org/10.1108/03090560710752429

[63] Sirieix, L. and Dubois, P.L. (1999) Vers un modèle qualité-satisfaction intégrant la confiance? Recherche et Applications en Marketing (French Edition), 14, 1-22. https://doi.org/10.1177/076737019901400301

[64] Aurier, Ph., Benavent, C. and N'Gola, G. (2001) Validité discriminante et prédictive des composantes de la relation a la marque. Cahiers de Recherche du CREGO, 8, 51-70.

[65] Veasna, S., Wu, W.Y. and Huang, C.H. (2013) The Impact of Destination Source Credibility on Destination Satisfaction: The Mediating Effects of Destination Attachment and Destination Image. Tourism Management, 36, 511-526.

https://doi.org/10.1016/j.tourman.2012.09.007

[66] Gouteron, J. (2008) L'impact de la personnalité de la marque sur la relation à la marque dans le domaine de la téléphonie mobile. La Revue des Sciences de Gestion, 4, 115-127. https://doi.org/10.1051/larsg:2008037

[67] Ayoubi, L. (2016) L'influence de la fidelité à la marque et de la fidelité au programme relationnel sur l'attitude des clients (cas des banques). Thèse de doctorat, École Doctorale Droit et Sciences Politiques Économiques et de Gestion, Université Nice Sophia-Antipolis.

[68] Fournier, S. (1998) Consumers and Their Brands: Developing Relationship Theory in Consumer Research. Journal of Consumer Research, 24, 343-373.

https://doi.org/10.1086/209515

[69] Garbarino, E. and Johnson, M.S. (1999) The Different Roles of Satisfaction, Trust, and Commitment in Customer Relationships. Journal of Marketing, 63, 70-87. https://doi.org/10.1177/002224299906300205

[70] Ambroise, L., Pantin-Sohier, G. and Valette-Florence, P. (2007) De la personnalité des célébrités à la personnalité des marques: Nouvelle démarche de sélection des ambassadeurs. Actes du XXIIİme Congrès International de P AFM, Aix-les-Bains, 31 mai-1er juin 2007, 1-36.

[71] Keller, E.B. and Berry, J.L. (2003) The Influentials: One American in Ten Tells the Other Nine How to Vote, Where to Eat, and What to Buy. Free Press, New York.

[72] Reichheld, F. and Schefter, P. (2000) E-Loyalty. Harvard Business Review, 78, 105-114.

[73] Urban, G.L., Sultan, F. and Qualls, W.J. (2000) Placing Trust at the Center of Your Internet Strategy. Sloan Management Review, 42, 39-48.

[74] Gommans, M., Krishnan, K.S. and Scheffold, K.B. (2001) From Brand Loyalty to E-Loyalty: A Conceptual Framework. Journal of Economic and Social Research, 3, 43-58.

[75] Singh, J. and Sirdeshmukh, D. (2000) Agency and Trust Mechanisms in Consumer Satisfaction and Loyalty Judgments. Journal of the Academy of Marketing Science, 28, 150-167. https://doi.org/10.1177/0092070300281014

[76] Beerli, A., Martin, J.D. and Quintana, A. (2004) A Model of Customer Loyalty in the 
Retail Banking Market. European Journal of Marketing, 38, 253-275. https://doi.org/10.1108/03090560410511221

[77] Ladhari, R. (2005) La satisfaction du consommateur, ses déterminants et ses conséquences. Revue de I Université de Moncton, 36, 171-201. https://doi.org/10.7202/014503ar

[78] Park, C.W., MacInnis, D.J. and Priester, J.R. (2006) Beyond Attitudes: Attachment and Consumer Behavior. Seoul National Journal, 12, 3-36.

[79] Bentler, P.M. and Bonett, D.G. (1980) Significance Tests and Goodness of Fit in the Analysis of Covariance Structures. Psychological Bulletin, 88, 588-606. https://doi.org/10.1037/0033-2909.88.3.588

[80] Browne, M.W. and Cudek, R. (1993) Alternative Ways of Assessing Model Fit. In: Bollen, K.A. and Long, J.S., Eds., Testing Structural Equation Models, Sage, Thousand Oaks, 136-162.

[81] Bollen, K.A. (1989) Structural Equations with Latent Variables. John Wiley \& Sons Inc., New York. https://doi.org/10.1002/9781118619179

[82] Browne, M.W. and Cudeck, R. (1993) Alternative Ways of Assessing Model Fit. In: Bollen, K.A. and Long, J.S., Eds., Testing Structural Equation Models, Sage, Thousand Oaks, 154, 136-136.

[83] Ailawadi, K.L., Neslin, S.A., Luan, Y.J. and Taylor, G.A. (2014) Does Retailer CSR Enhance Behavioral Loyalty? A Case for Benefit Segmentation. International Journal of Research in Marketing, 31, 156-167. https://doi.org/10.1016/j.ijresmar.2013.09.003

[84] Guenzi, P., Johnson, M.D. and Castaldo, S. (2009) A Comprehensive Model of Customer Trust in Two Retail Stores. Journal of Service Management, 20, 290-316. https://doi.org/10.1108/09564230910964408

[85] Koschate-Fischer, N., Cramer, J. and Hoyer, W.D. (2014) Moderating Effects of the Relationship between Private Label Share and Store Loyalty. Journal of Marketing, 78, 69-82. https://doi.org/10.1509/jm.13.0075

[86] Calvo Porral, C. and Levy-Mangin, J.P. (2016) Food Private Label Brands: The Role of Consumer Trust on Loyalty and Purchase Intention. British Food Journal, 118, 679-696. https://doi.org/10.1108/BFJ-08-2015-0299

[87] Belaid, S. and Temessek Behi, A. (2011) The Role of Attachment in Building Consumer-Brand Relationships: An Empirical Investigation in the Utilitarian Consumption Context. Journal of Product \& Brand Management, 20, 37-47. https://doi.org/10.1108/10610421111108003

[88] Pandowo, A. (2016) How to Create Brand Love in Private Label: The Role of Satisfaction as Intervening Variable. Journal of Marketing Management, 4, 81-91. https://doi.org/10.15640/jmm.v4n2a7 